\title{
Significance to the host of changes in fermentation activity
}

\author{
By P. C. Thomas and J. L. Clapperton, The Hannah Research Institute, \\ Ayr $K A 6{ }_{5} H L$
}

A large part of the inefficiency traditionally associated with the production of meat or milk by the ruminant animal is now known to result from the microbial fermentation of dietary energy and protein in the rumen. In this paper, the relationship between digestion and metabolism in the ruminant is considered and the nutritional implications of alterations in the extent and pattern of fermentation are discussed. No attempt is made to provide a comprehensive coverage of the literature since many of the topics dealt with have been recently reviewed (see Phillipson, I970) but attention is drawn to points of special significance in the context of the present symposium.

\section{The fate of food constituents}

The partition of energy within the digestive tract. During the past 10 years numerous methods have been used to investigate quantitative aspects of the partition of energy within the digestive tract and some of the results of these studies are summarized in Table I. The figures shown imply that there are wide variations in the pattern of digestion related to the diet and to other factors but unfortunately a meaningful description of these variations is prevented by the paucity of information and by the uncertainty attached to much of the information available.

Most research workers now give credence to the methods of measuring the flow of digesta through the intestines (see MacRae \& Armstrong, 1969) although there are still disputes about the use of marker substances and about the most suitable techniques for cannulation and sampling (Drennan, Holmes \& Garrett, 1970; Corse \& Sutton, 1971; Weller, Pilgrim, Gray, Taylor \& Reid, 1971). For the microbial wastes formed in the rumen only methane production can be stated with complete confidence. There are considerable reservations about the measurements of the rates of production of the short-chain fatty acids (see Sutton, 197I) and the heat of fermentation has, as yet, only been measured in in vitro batch culture incubations, mainly with 'cellulose' substrates (Marston, 1948; Walker, 1965; Houpt, 1968; Hersberger \& Hartsook, 1970).

Utilization of absorbed energy. The recognition that the substrates available to the tissues (see Table I) might vary with the pattern of digestion led Blaxter and his colleagues to begin their now classical studies of the utilization of infused energy sources in the fasting and fattening sheep. It was concluded (Blaxter, 1962) that the 
Table I. A summary of the partition of energy during digestion (figures are approximations based on values from the literature relating to the digestion of natural and processed foods in sheep)

\begin{tabular}{|c|c|c|c|c|}
\hline $\begin{array}{c}\text { Site of } \\
\text { digestion }\end{array}$ & $\begin{array}{c}\text { Amount of energy } \\
\text { 'disappearing' } \\
\text { (\% of the total } \\
\text { energy digested)* }\end{array}$ & $\begin{array}{l}\text { Main products of } \\
\text { digestion }\end{array}$ & $\begin{array}{l}\text { Composition of } \\
\text { mixtures of } \\
\text { short-chain fatty } \\
\text { acids (molar \%) }\end{array}$ & $\begin{array}{c}\text { Amounts of } \\
\text { individuals } \\
\text { products }(\% \text { of the } \\
\text { energy } \\
\text { disappearing) } \dagger\end{array}$ \\
\hline Rumen & $2.3-87$ & $\begin{array}{l}\text { Acetic acid } \\
\text { Propionic acid } \\
\text { Butyric acid } \\
\text { Methane } \\
\text { Heat } \$\end{array}$ & $\begin{array}{r}40-70 \\
14-40 \\
8-28\end{array}$ & $\begin{array}{l}75-88 \\
9-18 \\
3-7\end{array}$ \\
\hline $\begin{array}{l}\text { Small } \\
\text { intestine }\end{array}$ & $17-5 \mathrm{I}$ & $\begin{array}{l}\text { Amino acids } \\
\text { Sugars } \\
\text { Lipids§ }\end{array}$ & & $\begin{array}{r}30-62 \\
1-27 \\
37-43\end{array}$ \\
\hline $\begin{array}{l}\text { Caecum } \\
\text { and colon }\end{array}$ & $4-26$ & $\begin{array}{l}\text { Acetic acid } \\
\text { Propionic acid } \\
\text { Butyric acid } \\
\text { Methane } \\
\text { Heatf }\end{array}$ & $\begin{array}{c}66-74 \\
7-18 \\
4-8\end{array}$ & $\begin{array}{r}85 \\
9 \\
6\end{array}$ \\
\hline
\end{tabular}

* Calculated as the difference between intake and duodenal flow.

†Production rates of short-chain fatty acids determined by isotope dilution. Methane measured calorimetrically. Absorption from the small intestine calculated as the difference between duodenal and ileal flows.

Calculated as $6 \%$ of the energy fermented (Marston, 1948),

$\$$ Calculated from disappearance between the duodenum and facces.

efficiency of utilization of the mixture of short-chain fatty acids absorbed from the rumen had a negative correlation with the percentage of acetic acid absorbed and was lower than the efficiency of utilization of glucose or amino acids absorbed from the small intestine.

More recent work has provided support for the suggestion that acetic acid is poorly utilized in the fasting animal (Halter, Heald \& Colovos, 1970) but the low efficiency of utilization of acetic acid for fattening has yet to be confirmed (Bull, Reid $\&$ Johnson, I970; Lawrence and Thomas, unpublished).

The utilization of energy substrates for growth where a large part of the energy retained is protein has not been determined calorimetrically, but in comparative slaughter studies of energy retention (Bull et al. 1970; Hovell \& Greenhalgh, 1972) or carcass-weight gain (Ørskov \& Allen, 1966a,b,c; Ørskov, Hovell \& Allen, 1966; Poole \& Allen, I970) no statistically significant differences have been reported in the efficiency of utilization of diets supplemented with acetate, propionate or butyrate. Similarly, in calorimetric studies involving intraruminal infusions of short-chain fatty acids there is no evidence that the efficiency of utilization of energy for milk secretion is greatly influenced by the mixture of acids absorbed from the rumen (Armstrong \& Blaxter, 1965; Ørskov, Flatt, Moe \& Munson, 1969). Increases in the amount of propionic acid absorbed do, however, decrease the energy secreted as milk and promote the synthesis of adipose tissue. In comparison with the non- 
lactating animal the utilization of energy for adipose tissue synthesis appears to be especially efficient (Armstrong \& Blaxter, 1965 ).

At present, information is lacking on the utilization for growth and lactation of nutrients absorbed from the small intestine.

The influence of short-chain fatty acids on milk yields and on the composition of milk and body tissues. In the lactating cow intraruminal infusions of acetic acid are associated with increases in the volume of milk secreted and in the yields of all milk constituents. Also, both acetic and butyric acids give a specific improvement in milk-fat percentage. With propionic acid, fat content is depressed and there are increases in the solids-not-fat fraction reflecting mainly alterations in protein content (Rook \& Balch, 196r).

In growing animals intraruminal or dietary additions of acetic acid promote greater nitrogen retention than does the administration of a similar amount of energy as propionic or butyric acids (Rook, Balch, Campling \& Fisher, 1963 ; Ørskov \& Allen, I966c).

Utilization of protein. Because of the extensive hydrolysis of protein in the rumen and the exchange of nitrogen across the rumen mucosa (Smith, 1969) the flow of protein to the intestines may depend more on the synthesis of microbial cells than on the protein content of the diet (Hogan \& Weston, 1970). The growth of bacterial cultures under energy-limiting conditions in vitro is closely related to the energy available to the organisms as ATP (Bauchop \& Elsden, I960) and ruminal protein synthesis is thought to depend mainly on the energy derived from fermentation. However, when the concentration of crude protein in the diet is less than $10 \%$, nitrogen may become limiting (Hume, Moir \& Somers, I970).

For bacteria, $6 \cdot 2-12 \cdot 5 \mathrm{~g}$ crude protein are synthesized per mol of ATP consumed (Bauchop \& Elsden, 1960; Hobson \& Summers, 1967), but rates of synthesis attributable to the whole rumen population may vary over an even wider range because of the presence of the protozoa. Values in the literature indicate that the total flow of crude protein $(\mathrm{N} \times 6 \cdot 25)$ and the flow of crude bacterial protein from the rumen may vary respectively from $7^{-32} \mathrm{~g}$ and from $4^{-23} \mathrm{~g}$ per $100 \mathrm{~g}$ organic matter fermented (Hogan \& Weston, 1970; Hume, 1970; Ishaque, Thomas \& Rook, 1971 ; Jackson, Rook \& Towers, 1971 ; Sutton, 1971), and under some circumstances, the variations in yield are associated with the mixture of short-chain fatty acids formed (Hume, 1970; Ishaque et al. 1971; Jackson et al. 1971). The basis of this effect is unknown but could relate either to changes in the microbial population and thus the molar growth yield or to changes in the yield of ATP produced by fermentation.

If the demand for protein is high, as in the dairy cow, and the rate of synthesis of microbial protein is low, the flow of nitrogen to the intestine may barely meet the animal's requirements for nitrogen. More commonly the amounts of certain essential amino acids available to the tissues will limit protein synthesis. For muscle synthesis, methionine may be the first limiting amino acid (Hutton \& Annison, I972) and the sulphur amino acids are also thought to limit wool growth (Reis, I967). For milk-protein synthesis the position is less clear and various amino acids have 
been claimed to be limiting including lysine, methionine, phenylalanine, histidine and leucine (Schelling \& Hatfield, I968; Brown, I969; Mepham, 1971) and the nonessential amino acid, glutamic acid (Halfpenny, Smith \& Rook, 1969). The last suggestion has a special significance since the provision of glutamic acid to the mammary gland may be enhanced by an increased absorption of propionic acid from the rumen (Halfpenny et al. 1969).

\section{Factors infuencing the pattern and extent of fermentation in the rumen}

The composition of the mixtures of short-chain fatty acids formed and the amount of methane produced during fermentation are influenced by the chemical composition and physical form of the diet (Blaxter, 1962; Thomson, 1972), by the level and frequency of feeding (Blaxter, 1962; Eadie $\&$ Mann, I970), by rumen $\mathrm{pH}$ (Sutton, 1971), by chemical additives (Alhassan, Krabill \& Satter, 1969; Farra \& Satter, 1971; Trei, Parrish, Singh \& Scott, 197I ; Czerkawski, 1972) and by other factors relating to the microbial population. Long-roughage diets, typically, are associated with a high proportion of acetic acid $(65-74 \%$ on a molar basis), a low proportion of propionic acid ( $15-19 \%)$ and a variable proportion of butyric acid $(8-16 \%)$. When the forage is finely ground or mixed with concentrates or the level of feeding is increased, the proportion of acetic acid is usually, although not invariably, decreased and there are associated increases in propionic acid, butyric acid or both. With some diets wide variations in the mixture of short-chain fatty acids can occur even when there is rigid control of feeding (Ishaque et al. 1971 ; Lawrence \& Thomas, 1972). Since the formation of methane and of propionic acid requires hydrogen (Hungate, I966), methane production varies with the mixture of short-chain fatty acids formed and is low when the percentage of propionic acid is high.

The extent of fermentation in the rumen is reduced by any change in the microbial population which decreases the intensity of digestive activity towards a particular substrate. For example, competition between amylolytic and cellulolytic organisms may lead to a decrease in the number of cellulose digesters and a depression in the digestion of the fibrous part of the food. It is also possible to achieve a transfer in the site of digestion from the rumen to the small intestines via an increased synthesis of microbial cells (Ishaque et al. 197I; Jackson et al. 1971).

\section{The nutritional significance of changes in fermentation activity}

Nitrogen absorbed from the rumen has no immediate nutritional value so that changes in fermentation leading to an enhanced flow of either dietary or microbial protein to the intestines must produce benefits in the supply of amino acids to the tissues. Dietary protein has an additional quality in that it may be rich in the amino acids which are in low concentration in the microbes. In vivo the flow of total and bacterial protein to the intestines has been correlated with the molar percentage of propionic acid in the rumen fluid (Ishaque $t$ t al. $197 \mathrm{I}$; Jackson $\boldsymbol{e t}$ al. 1971) and there is circumstantial evidence that this relationship may have a more general applicability (Meyer, Bartley, Deyoe \& Colenbrander, 1967; Nicholson \& Sutton, 1969). However, 
it should be recognized that such correlations merely serve to indicate more fundamental variations in the energetics of fermentation.

The position with regard to the utilization of dietary energy is complex and, in quantitative terms, only poorly described. A change in microbial activity producing an increased flow of dietary or microbial calories to the duodenum may be accompanied by changes in the energy absorbed as short-chain fatty acids, lost as heat and methane or excreted in the faeces. Also, associated changes in the mixture of acids absorbed from the rumen or in the balance between nutrients absorbed from the rumen and from the intestines may alter the pattern of metabolism within the host and the utilization of absorbed energy. In some instances improved efficiency in one direction will be offset by diminished efficiency in another. For example, the metabolizable-energy content of the diet can be increased by changes in fermentation associated with a decrease in methane production, but often such changes are linked with a reduced ruminal cellulolysis and an increased faecal loss of energy (Clapperton \& Czerkawski, I97I; Lawrence \& Thomas, 1972).

There is little direct information about the effect of a change in fermentation activity on the utilization of apparently absorbed energy. However, there is ample evidence that changes in fermentation, and presumably other aspects of digestion, associated with changes in the chemical composition of the diet, influence the composition of milk secreted and the utilization of metabolizable energy (Blaxter, 1962; Armstrong, 1968; Annison \& Armstrong, 1970). In recent studies it has been possible to obtain wide variations in fermentation with a single diet (Lawrence \& Thomas, I972) and, under these conditions, the efficiency of utilization of metabolizable energy for fattening $(\mathrm{Y})$ is inversely related to the molar percentage of acetic acid in rumen fluid $(\mathrm{X})$ such that $\mathrm{Y}=\mathrm{I} 4 \mathrm{r}-\mathrm{r} \cdot 70 \mathrm{X}$. This relationship has a striking similarity to that reported by Blaxter ( 1962$)$ with a range of $\operatorname{diets}\left(\mathrm{Y}=\mathrm{I}_{3} 8\right.$ $-\mathrm{r} \cdot 59 \mathrm{X}$ ) and indicates that the efficiency of utilization of metabolizable energy is determined mainly by the pattern of digestion. On this basis there may be considerable scope for influencing the efficiency of utilization of dietary energy. The relationship also implies that there is a degree of 'stoichiometry' between the products of digestion since it appears that changes in the mixture of substrates absorbed from the rumen and intestines can be characterized by reference to acetic acid.

A few studies have been made of the effect on the utilization of energy of chemical additives which modify fermentation. In experiments using chloroform as a methane inhibitor, changes in methane production and in the mixture of short-chain acids in the rumen have been associated with the expected increases in energy retention (Clapperton \& Czerkawski, I972). In contrast, 2,2,2-trichloroacetamide, a methane inhibitor; nitrate, a hydrogen acceptor; and sulphite, an acetate inhibitor, have had only small effects on growth or on milk composition (Alhassan et al. r 969; Farra \& Satter, 1971; Trei et al. 1971). This variability in response highlights the complexity of the relationship between fermentation and energy metabolism in the whole animal and underlines the need for systematic quantitative studies of the interrelationships between two products of digestion and of the effects of a change in the products of digestion on the utilization of nutrients within the tissues of the host. 


\section{REFERENCES}

Alhassan, W. S., Krabill, L. F. \& Satter, L. D. (1969). F. Dairy Sci. 52, 376.

Annison, E. F. \& Armstrong, D. G. (1970). In Physiology of Digestion and Metabolism in the Ruminant p. 422 [A. T. Phillipson, editor]. Newcastle upon Tyne: Oriel Press Ltd.

Armstrong, D. G. (1968). Proc. Nutr. Soc. 27, 57.

Armstrong, D. G. \& Blaxter, K. L. (1965). In Energy Metabolism p. 59 [K. L. Blaxter, editor]. London: Academic Press.

Bauchop, T. \& Elsden, S. R. (1960). F. gen, Microbiol. 23, 457.

Blaxter, K. L. (I962). The Energy Metabolism of Ruminants. London: Hutchinson.

Brown, R. E. (1969). In University of Nottingham Third Nutrition Conference for Feed Manufacturers p. 23 [H. Swan and D. Lewis, editors]. London: J. \& A. Churchill.

Bull, L. S., Reid, J. T. \& Johnson, D. E. (I970). F. Nutr. 1oo, 262.

Clapperton, J. L. \& Czerkawski, J. W. (1971). Br. F. Nutr. 26, 459.

Clapperton, J. L. \& Czerkawski, J. W. (1972). Proc. Nutr. Soc. 3I, 55A.

Corse, D. A. \& Sutton, J. D. (I97I). Proc. Nutr. Soc. 30, 18A.

Czerkawski, J. W. (I972). Rep. Hamnah Res. Inst. I97 I p. 40.

Drennan, M. I., Holmes, J. H. G. \& Garrett, W. N. (1970). Br. F. Nutr. 24, 96r.

Eadie, J. M. \& Mann, S. O. (1970). In Physiology of Digestion and Metabolism in the Ruminant p. 335 [A. T. Phillipson, editor]. Newcastle upon Tyne: Oriel Press Ltd.

Farra, P. A. \& Satter, L. D. (1971). F. Dairy Sci. 54, 1018.

Halfpenny, A. F., Rook, J. A. F. \& Smith, G. H. (1969). Br. Y. Nutr. 23, 547.

Halter, J. B., Heald, C. W. \& Colovos, N. F. (r970). J. Dairy Sci. 53, 1241.

Hersberger, T. V. \& Hartsook, E. W. (1970). F. Anim. Sci. 30, 257.

Hobson, P. N. \& Summers, R. (1967). F. gen. Microbiol. 47, 53 .

Hogan, J. P. \& Weston, R. H. (1970). In Physiology of Digestion and Metabolism in the Ruminant p. 474 [A. T. Phillipson, editor]. Newcastle upon Tyne: Oriel Press Ltd.

Houpt, T. R. (1968). Am. F. vet. Res. 29, 411 .

Hovell, F. D. DeB. \& Greenhalgh, J. F. D. (1972). Proc. Nutr. Soc, 3r, 68A.

Hume, I. D. (1970). Aust. F. agric. Res. 21, 297.

Hume, I. D., Moir, R. J. \& Somers, M. (1970). Aust. F. agric. Sci. 2r, 283.

Hungate, R. E. (1966). The Rumen and Its Microbes. New York and London: Academic Press.

Hutton, K. \& Annison, E. F. (1972). Proc. Nutr. Soc. 31, I 5 I.

Ishaque, M., Thomas, P. C. \& Rook, J. A. F. (x971). Nature, New Biology 231, 253.

Jackson, P., Rook, J. A. F. \& Towers, K. G. (1971). F. Dairy Res. 38, 33 .

Lawrence, P. \& Thomas, P. C. (1972). Proc. Nutr. Soc. 31, 49 A.

MacRae, J. C. \& Armstrong, D. G. (1969). Br. F. Nutr. 23, I5.

Marston, H. R. (1948). Biochem. F. 42, 564.

Mepham, T. B. (I97 I). In Lactation p. 297 [I, Falconer, editor]. London: Butterworths.

Meyer, R., Bartley, E. E., Deyoe, C. W. \& Colenbrander, V. F. (1967). F. Dairy Sci. 50, 1327.

Nicholson, J. W. G. \& Sutton, J. D. (I 969). Br. F. Nutr. 23, 585.

Ørskov, E. R. \& Allen, D. M. (1966a). Br. F. Nutr. 20, 295.

Ørskov, E. R. \& Allen, D. M. (Ig66b). Br. Y. Nutr. 20, 509.

Ørskov, E. R. \& Allen, D. M. (1966c). Br. F. Nutr. 20, 519.

Ørskov, E. R., Flatt, W. P., Moe, P. W. \& Munson, A. W. (1969). Br. F. Nutr. 23, 443.

Orskov, E. R., Hovell, F. D. \& Allen, D. M. (1966). Br. F. Nutr. 20, 307.

Phillipson, A. 'T. (editor) (1970). Physiology of Digestion and Metabolism in the Ruminant. Newcastle upon 'Tyne: Oriel Press Ltd.

Poole, D. A. \& Allen, D. M. (1970). Br. F. Nutr. 24, 695.

Reis, P. J. (1967). Aust. F. biol. Sci. 20, 809 .

Rook, J. A. F. \& Balch, C. C. (1961). Br. F. Nutr. 15, 36г.

Rook, J. A. F., Balch, C. C., Campling, R. C. \& Fisher, L. J. (1963). Br. F. Nutr. 17, 399.

Schelling, G. 'T. \& Hatfield, E. E. (1968). J. Nutr. 96, 3 I9.

Smith, R. H. (1969). F. Dairy Res. 36, 3 г 3 .

Sutton, J. D. (1971). Proc. Nutr. Soc. 30, 243.

Thomson, D. J. (1972). Proc. Nutr. Soc. 31, 127.

Trei, J. E., Parrish, R. C., Singh, Y. K. \& Scott, G. C. (1971). Y. Dairy Sci. 54, 536.

Walker, D. J. (I965). In Physiology of Digestion in the Ruminant p. 296. [R. W. Dougherty, editor]. Washington, DC: Butterworths.

Weller, R. A., Pilgrim, A. F., Gray, F. V., Taylor, M. N. \& Reid, C. S. W. (197 I). Br. F. Nutr, 26, 487 . 